\title{
The Effect of Parental Academic Achievement Pressure perceived by Middle School Students on Academic Procrastination: The Mediating Role of Evaluative Concerns Perfectionism
}

\author{
Hana Joo ${ }^{1}$, Ju Hee Park² \\ M.A., Department of Child \& Family Studies, Yonsei University, Seoul, Korea ${ }^{1}$ \\ Professor, Department of Child \& Family Studies, Yonsei University, Seoul, Korea \\ 중학생이 지각한 부모의 학업성취압력이 학업지연행동에 미치는 영향과 \\ 평가염려 완벽주의의 매개효과 \\ 주하나 ${ }^{1}$, 박주희 ${ }^{2}$ \\ 연세대학교 아동가족학과 석사 ${ }^{1}$, 연세대학교 아동가족학과 교수 ${ }^{2}$
}

Objectives: This study aimed to examine the mediating effect of evaluative concerns perfectionism on the relationship between parental academic achievement pressure perceived by middle school students and their academic procrastination.

Methods: The study participants were 522 middle school students from first to third grade from three middle schools located in Gunsan, Iksan, and Jeonju. All data were analyzed using descriptive statistics and Pearson's correlation coefficients. Structural equation modeling was also used to investigate the mediating model.

Results: The result of this study showed that the level of parental academic achievement pressure perceived by middle school students increased their level of academic procrastination. In addition, the level of students' evaluative concerns perfectionism increased the level of their academic procrastination. Second, middle school students' evaluative concerns perfectionism partially mediated the relationship between parental academic achievement pressure perceived by them and their academic procrastination. That is, the higher the level of parental academic achievement pressure, the higher the level of evaluative concerns perfectionism, and consequently, the higher the middle school students' academic procrastination.

Conclusion: The outcomes suggest that it is important for parents to set proper expectations for their children and provide them with sufficient support, such as respecting their autonomy in academic decision-making to prevent students' academic procrastination. In addition, interventions to change maladaptive cognitive beliefs including evaluation concerns perfectionism would help students reduce their academic procrastination. In conclusion, these findings suggest several ways to prevent and decrease middle school students' academic procrastination by empirically verifying predictors on academic procrastination.

Keywords: middle school students, academic procrastination, parental academic achievement pressure, evaluative concerns perfectionism

Corresponding Author: Ju Hee Park, Professor, Department of Child \& Family Studies, Yonsei University, 50, Yonsei-ro, Seodaemun-gu, Seoul, Korea

E-mail: juheepark@yonsei.ac.kr
(c)The Korean Association of Child Studies

This is an Open Access article distributed under the terms of the Creative Commons Attribution Non-Commercial License (http:// creativecommons.org/licenses/by-nc/4.0) which permits unrestricted noncommercial use, distribution, and reproduction in any medium, provided the original work is properly cited. 


\section{Introduction}

해야 할 일을 미루는 것은 대다수 사람들이 보일 수 있는 보 편적인 행동이지만, 이것이 만성화 되거나 개인의 생활에 불 이익을 초래한다면 문제가 된다. 연구자들은 미래에 발생할 수 있는 피해나 주관적 불편감을 개인이 인식하고 있음에도 불구하고 해야 할 일을 불필요하게 미루는 행동을 지연행동 (procrastination)이라고 정의하며, 미루는 행동의 본질을 이해 하려고 시도해왔다(Solomon \& Rothblum, 1984; Steel, 2007). 지연행동은 생활 영역의 전반에서 나타날 수 있지만 그 중 학 업 장면에서 예정된 시간까지 과제를 시작하거나 완성하는 데에 실패하는 것을 학업지연행동이라 한다(Ellis \& Knaus, 1979). 학업지연행동은 학업이 주된 과업이자 학업적 성취를 이루는 것이 권장되는 시기에 있는 청소년들에게서 주로 나 타나 학교생활과 학업에서 소진을 불러일으키고 학업 성취 를 어렵게 할 수 있다(Cerino, 2014; Katz, Eilot, \& Nevo, 2014; Tice \& Baumeister, 1997). 또한 낮은 자존감 및 불안, 우울과 영향을 주고받으며 궁극적으로 주관적 삶의 만족도를 하락 시킬 수 있다는 점에서(Spada, Hiou, \& Nikcevic, 2006; Steel, Brothen, \& Wambach, 2001; Steel \& Klingsiek, 2016) 청소년의 학업지연행동을 감소시키기 위한 개입 방안을 고안하는 것 이 필요하다.

특히 중학생은 이전과 비교하여 학습량과 학업 난이도가 급격히 증가하는 것을 경험하고 평가적 상황에 더 자주 놓 이게 되어 학습 환경의 변화와 부담이 커지는 시기이다(Yoo, 2007). 이와 같은 중학생 시기의 특성은 지연행동을 보이 게 할 가능성을 높이며(Spada et al., 2006), 한 번 형성된 지연 행동은 만성화되고 개인의 특성으로 고착될 수 있다(Lay \& Schouwenburg, 1993). 따라서 학습 환경이 전환되는 중학생의 학업지연행동에 대한 기제를 파악하는 것은 그들이 학업 목표 를 달성하도록 도울 수 있을 뿐만 아니라 이후 삶에서의 성취 를 이루는 것과도 관련이 있다는 점에서 중요하다.

연구자들은 학업지연행동을 예측하는 변인에 대한 다양한 연구들을 진행해왔는데 특히 부모의 양육 변인이 청소년들의 학업지연행동을 예측하는 데 주요한 요인이 될 수 있다는 점 을 강조해왔다(E. B. Ahn \& Kim, 2020; Baek \& Lee, 2016; N.-K. Kim \& Han, 2019; Milgram \& Toubiana, 1999; Zakeri, Esfahani, $\&$ Razmjoee, 2013). 구체적으로 몇몇 선행연구들은 부모가 자 녀에 대해 가지는 높은 수준의 교육적 관심, 학업 성취 기대에 따라 자녀에게 가하는 압력을 의미하는 부모의 학업성취압력 이 학업지연행동에 미치는 영향에 주목하였다(H.-Y. Ahn \&
Han, 2019; S.-Y. Lee, Kim, \& Bong, 2016).

부모의 학업성취압력은 부모가 자녀에게 높은 수준의 학 업성취를 이룰 것을 요구하고 학업과 관련된 행동을 제한하 고 통제한다는 점에서 권위적(authoritarian)이고 통제적인 양 육태도와 맥을 같이한다고 볼 수 있다. 선행연구들은 이와 같 은 부모의 양육태도가 자녀로 하여금 자신이 해야 할 일을 자 율적으로 수행하고 그에 따른 책임감을 기를 수 있는 기회를 감소시킴으로써 지연행동을 유발함을 지적하면서 부모의 통 제적이고 권위적인 양육태도가 학업지연행동에 영향을 미치 는 요인임을 보여주었다(Soysa \& Weiss, 2014; Won \& Shirley, 2018), 즉 학업에 대한 통제적이고 권위적인 양육태도인 부모 의 학업성취압력은 자녀의 자율적 태도를 저해하고 수동적인 태도를 유발하여 결국 학업 장면에서의 지연행동에 이르게 할 수 있다(Bong, Hwang, Noh, \& Kim, 2014).

또한 학업지연행동은 제한된 시간 내에 해야 할 일을 완 수하지 못하고 불필요한 지연을 보이는 부적응적인 행동 특 성이라는 점에서 자기조절능력(self-regulation)의 실패로 인 한 행동이며, 학업목표를 달성하기 위한 능동적이고 전략적 인 학습을 의미하는 자기조절학습(self-regulated learning)과 는 반대되는 행동 양상이라고 볼 수 있다(Steel, 2007; Won $\&$ Shirley, 2018). Deci와 Ryan $(2000,2002)$ 의 자기결정이론 (self-determination theory)에 따르면 자녀가 부모의 자율적이 고 지지적인 양육태도를 지각하고 있을 때, 자기조절능력을 발달시켜 주도적이고 계획적인 학습행동을 보이게 될 수 있 다. 반대로 성취에 대한 부모의 지나친 우려는 자녀를 통제하 는 것에 초점을 둔 양육태도를 보이게 하는데 이렇게 외적으 로 통제된 자녀들은 학습에 대한 주도성과 책임감을 발달시 키기 어려워 자기조절학습 능력이 저해될 수 있다(Deci et al., 1994; Vansteenkiste, Lens, \& Deci, 2006; Won \& Shirley, 2018). 이를 종합하면, 자율적이고 지지적인 양육태도와는 반대로 권위적이고 통제적인 특징을 갖는 부모의 학업성취압력은 자녀의 학업지연행동을 예측하는 요인으로 작용될 수 있음 을 예측해볼 수 있다.

그러나 이와 같은 부모의 양육태도가 어떠한 경로를 통해 자녀의 학업지연행동에 영향을 미치는지에 대한 연구는 충분 히 이루어지지 못하고 있는 실정이다. 부모의 양육태도가 학 업 상황에서의 자녀의 행동에 미치는 영향을 탐구한 최근 선 행연구들(Fletcher, Shim, \& Wang, 2012; Soysa \& Weiss, 2014; Won \& Shirley, 2018)은 Bandura (1999)의 사회인지이론(social cognitive theory)을 통해 두 변인들 간의 관계에 대한 설명을 시 도하였는데, 본 이론에 따르면 자녀들은 부모의 양육태도와 
반응 등을 통해 내적 모델을 형성하고 이를 토대로 이후의 행 동을 보인다고 설명하였다. 이를 본 연구에 적용하면, 부모의 학업성취압력이 자녀로 하여금 내적 모델을 형성하게 하고 이 러한 내적 요인이 간접적으로 학업지연행동의 형성에 영향을 미칠 수 있음을 가정해볼 수 있다. 실제로 사회인지 이론적 관 점에 기초하여 부모의 양육태도와 지연행동 간 관계를 살펴본 Soysa와 Weiss (2014)의 연구는 부모의 지나친 통제와 수용의 부족은 자녀로 하여금 부모의 비현실적 기준을 충족시켜야 한 다는 인식을 내면화 시키고 지연행동을 일으키는 환경적 맥락 으로 작용할 수 있음을 보여주었다.

한편, 연구자들은 지연행동이 불쾌한 자기 인식에서 벗어 나 일시적으로 고통을 회피할 수 있는 수단을 제공하기 때문 에, 수행 상황에서 자신의 취약성을 드러내는 것에 대한 두려 움과 부정적 자기 인식을 가진 개인은 지연행동을 보일 수 있 으며 이러한 성격적 특성은 그 동안의 환경적, 사회적 요구에 대처하며 형성된 결과임을 언급하였다(Díaz-Morales, Cohen, \& Ferrari, 2008; Steel, 2007). 이와 관련하여 평가염려 완벽주 의는 부모의 학업성취압력과 학업지연행동 간 관계를 매개하 는 요인이 될 수 있는데, 이는 자신의 행동에 대한 지나친 비판 과 함께 타인의 비판에 대해 지속적으로 염려하며 완벽해지 려는 특성으로 정의되며 자신을 향한 평가에 대한 우려와 자 기 비난적인 특성이 두드러진다(Dunkley, Blankstein, Halsall, Williams, \& Winkworth, 2000). 이러한 점에서 평가염려 완벽 주의는 지연행동을 유발하는 개인의 성격적 특성으로 선행할 수 있으며 이는 부모의 학업성취압력과 같은 환경적 요구에 따라 형성되었을 가능성이 높아 매개변인으로서 그 경로를 살 펴볼 가치가 있을 것이다.

우선 평가염려 완벽주의의 매개효과는 평가염려 완벽주의 의 특성이 부모의 학업성취압력에 의해 형성된다는 선행연구 들의 결과에 의해 뒷받침될 수 있다(Fletcher et al., 2012; Miller, Lambert, \& Speirs Neumeister, 2012). 부모의 학업성취압력은 자녀들로 하여금 학업 과정보다는 결과 위주의 성취만을 중 시하게 하여 스스로 높은 기준을 설정하고 완벽해지려고 하 기보다는 부모가 세운 과도한 기준과 목표에 도달해야만 한 다는 인식을 가지게 할 수 있다. 이 과정에서 부모의 기대를 쉽 게 충족시킬 수 없다는 인식이 누적되면 자신의 실수나 실패 를 용납하지 않으려는 완벽주의 성향을 내면화하게 될 수 있 다(Hamachek, 1978). 더 나아가 부모의 과도한 기대 수준은 자 녀가 성취한 결과에 대해 주로 부정적으로 평가하게 만드는 데, 이에 자녀는 부모에게 좋지 않은 평가를 받을 것이 예상되 어 심리적 부담을 느끼고 부모의 평가에 따라 자신을 비난하
는 평가염려 완벽주의를 내면화 할 수 있다. 이는 자녀가 부모 의 높은 기대를 인식하는 것이 완벽주의의 주요한 요인이며 자녀에게 가하는 과도한 성취압력은 부모에게 인정받거나 비 난을 피하고자 하는 부적응적 완벽주의를 갖게 한다는 선행연 구 결과에 의해 지지될 수 있다(Hibbard \& Walton, 2014; Y. Lee $\&$ Joeng, 2016).

또한 평가염려 완벽주의는 학업지연행동을 직접 예측하 는 변인으로도 작용할 수 있다(Burnam, Komarraju, Hamel, \& Nadler, 2014; Closson \& Boutilier, 2017; Soysa \& Weiss, 2014; Xie, Yang, \& Chen, 2018). 두 변인 간의 관계는 Lazarus와 Folkman (1984/2001)의 스트레스 상황에 대처하는 인지-정서행동 이론으로 설명될 수 있다(Hashemi \& Latifian, 2014). 이에 따르면, 사람들은 주어진 상황이나 과제가 자신에게 위협적인 지와 이에 대처할 수 있는 내적 - 외적 자원을 보유하고 있는지 에 대한 일련의 인지적 평가에 따라 스트레스 상황에서의 대 처방법에 대한 결정을 내린다. 만약 자신의 자원이 불충분하 다고 인식하면 불안감을 경험하고, 이를 유발하는 일을 미룸 으로써 그 상황에서 벗어날 수 있으며, 부정적 정서 또한 감소 시킬 수 있기 때문에 지연행동이 부적강화 될 수 있다(Milgram $\&$ Tenne, 2000). 만약 평가염려 완벽주의와 같은 역기능적 인 지 신념을 가진 학생이 학업 상황에 있을 경우, 실패가 가져올 주변의 평가에 대한 염려와 자신의 수행에 대해 의심함으로써 발생하는 자기 비난적 정서를 회피하기 위해 학업지연행동을 나타낼 것이라고 예측해볼 수 있다.

앞서 살펴본 것을 종합해보면 부모의 학업성취압력은 중 학생의 평가염려 완벽주의와 학업지연행동에 영향을 미치고, 평가염려 완벽주의 특성은 학업지연행동의 발생에 영향을 줄 수 있음을 가정해볼 수 있다. 즉 부모의 학업성취압력과 중학 생의 학업지연행동 간의 관계를 평가염려 완벽주의가 매개할 수 있다는 것이다. 이렇듯 세 변인 간의 관련성에 따라 그 경로 와 양상을 구체적으로 살펴볼 수 있음에도, 이러한 가설을 규 명한 연구는 드물게 진행되어 충분한 경험적 검증의 필요성이 추가로 요구된다. 또한 기존의 연구들은 전반적인 일상생활에 서 부모의 양육태도와 학업지연행동 간 관계를 탐색하였지만 (E. B. Ahn \& Kim, 2020; Baek \& Lee, 2016; N.-K. Kim \& Han, 2019; H. Park \& Lee, 2020) 학업지연행동의 경우, 학업 수행 상황에서 자신에게 요구되는 성취 기준을 충족시키지 못할 것 이라는 두려움에 의해 발생하는 부적응 행동이기 때문에 위와 같은 특성을 측정할 수 있는 부모의 영향력을 살펴볼 필요가 있다. 그럼에도 불구하고, 학업지연의 예측변인으로서 부모의 권위적 양육태도, 심리적 통제 등을 살펴본 기존 연구들의 측 
정문항을 살펴보면, 부모로부터 요구되는 학업 성취 기준의 충족 가능 여부가 학생들로 하여금 두려움을 유발하는지에 대 하여 타당하게 측정하지 못해 변인 간 관계가 명확하지 못했 을 가능성이 있다. 따라서 본 연구에서는 학업 상황에서 위와 같은 부모의 영향력을 보다 면밀하게 측정할 수 있는 부모의 학업성취압력을 학업지연행동의 예측 변인으로 포함시켜 두 변인 간 관련성을 살펴보고자 하였다.

이에 더하여 우리나라의 경우 학업에서의 성취가 사회적 지위 뿐 아니라 부를 축적할 수 있는 유일한 계층이동의 사다 리로 인식되고 있으며, 부모세대의 높은 교육열이 자녀세대에 그대로 투영되는 사회적 분위기가 타문화보다 더욱 강력하게 조성되어 있다. 또한 중학생 시기는 이전과 비교하여 더욱 높 은 수준의 학업 성취를 이룰 것이 요구되어 이 시기의 부모는 학업 성취와 관련하여 자녀에게 더 많은 압력을 가하게 될 수 있다. 이렇듯 학업에 관한 문화적 인식과 중학생 시기의 특성 에 의해 부모가 학업 성취에 관한 압력을 행사할 가능성이 높 아짐에 따라, 이들을 대상으로 학업 상황 내에서의 양육태도 인 학업성취압력의 영향력을 살펴보는 것은 의미 있는 과제라 할 수 있을 것이다.

이상을 토대로 본 연구에서는 중학생들을 대상으로 하여 부모의 학업성취압력이 평가염려 완벽주의를 매개로 이들의 학업지연행동에 영향을 미치는지 살펴보고자 한다. 이때 학 업지연행동 수준이 남학생보다 여학생이 낮고(Zakeri et al., 2013) 학년이 높아질수록 증가하며(Rosário et al., 2009) 학업 성취도와는 부적 관계가 있다는(Sæle et al., 2017; Steel, 2007) 선행연구 결과들을 토대로 성별, 학년, 학업성취도를 통제변 인으로 포함하여 분석하고자 한다. 본 연구의 결과는 부모의 학업성취압력이 평가염려완벽주의를 매개로 하여 자녀의 학 업지연행동에 미치는 영향의 경로에 대한 이해를 증진시키고 이를 기반으로 중학생의 학업지연행동에 개입하기 위한 환경 및 개인적 차원에서의 방안을 마련하는 데 도움을 줄 수 있을 것이다.

\section{연구문제 1}

중학생이 지각한 부모의 학업성취압력과 평가염려 완벽주의는 학업지연행동에 유의한 영향을 미치는가?

\section{연구문제 2}

중학생이 지각한 부모의 학업성취압력이 학업지연행동에 미치 는 영향을 평가염려 완벽주의가 유의하게 매개하는가?

\section{Methods}

\section{연구대상}

본 연구는 군산시, 익산시, 전주시에 위치한 세 개 중학교에 재 학 중인 1-3학년 학생 522명을 대상으로 하였다. 연구 대상의 선정은 편의표집 방식으로 이루어졌으며 온라인을 통해 조사 가 진행되었다. 연구대상은 남학생이 294명(56.3\%), 여학생이 228 명(43.7\%)으로 남학생이 다소 많았으며 학년 별 구성에 있 어서는 1학년 183명(35.1\%), 2학년 164명(31.4\%), 3학년 175 명(33.5\%)으로 나타났다.

\section{연구도구}

\section{학업지연행동}

중학생의 학업지연행동을 측정하기 위해 Aitken (1982)의 지 연행동 척도(Aitken procrastination inventory)를 Jeon (2014)이 청소년에 맞게 수정·보완한 척도를 사용하였다. 이 척도는 총 15 개 문항으로 구성되어 있으며, 각 문항은 전혀 그렇지 않다 (1점)부터 매우 그렇다(5점)까지의 5점 리커트 척도로 평정하 도록 되어있다. 7 개 문항 $(3,5,9,10,12,13,14$ 번)은 역채점하 도록 되어있고 문항의 예로는 "나는 마지막 순간까지 시험공 부나 숙제를 시작하지 않고 미룬다.”, “나는 종종 숙제를 끝내 야 할 시간이 다 되어서야 허둥지둥 서두른다.” 등의 내용을 포함한다. 점수가 높을수록 학업 장면에서 예정된 시간까지 과제를 시작하거나 완성하는데 실패하는 행동을 보일 가능성 이 높다는 것을 의미한다. 본 연구에서 산출된 내적합치도 계 수 Cronbach's $\alpha$ 는 .88이었다.

\section{부모의 학업성취압력}

부모의 학업성취압력을 측정하기 위해 Y. C. Kang (2003)의 척 도를 사용하였다. 부모의 양육태도는 부모의 주관적인 판단 보다는 자녀의 지각과 해석 방식에 따라 다르게 평가될 수 있 다는 선행연구들(E. B. Ahn \& Kim, 2020; Soysa \& Weiss, 2014) 에 따라, 중학생이 지각한 부모의 학업성취압력을 측정하였 다. 이 척도는 자녀가 부모의 성취압력을 어떻게 지각하고 있 는지에 대해 측정하며 총 15 개 문항으로 구성되어 있다. 각 문 항은 전혀 그렇지 않다(1점)부터 매우 그렇다(5점)까지 5점 리 커트 척도로 평정하도록 되어있으며 문항의 예시로는 "부모 
님은 나에게 남보다 더 좋은 성적을 얻어야 한다고 말씀하신 다." "부모님은 친구들과 노는 시간을 제한하시는 편이다.” 등 이 있다. 점수가 높을수록 중학생이 부모가 학업성취압력을 많이 가한다고 지각하는 것을 의미한다. 본 연구에서 산출된 내적합치도 계수 Cronbach's $\alpha$ 는 .89이었다.

\section{평가염려 완벽주의}

평가염려 완벽주의는 Frost 등(1990)이 개발한 다차원적 완벽 주의 척도(Frost Multidimensional Perfectionism Scale [FMPS])를 Chung (1999)이 번안한 것을 사용하였으며, 원척도는 총 35 개 문항 6 개 하위요인으로 구성되어 있지만 본 연구에서는 평 가염려 완벽주의를 측정하는 두 개의 하위차원인 '실수에 대 한 염려' 9개 문항과 ‘수행에 대한 의심' 4 개 문항만을 사용하 였다. 이는 두 하위 차원이 부적응적 완벽주의의 핵심적 특성 인 자기 비난적 속성과 평가적 우려를 가장 잘 반영하는 차원 임을 밝힌 선행연구들에 근거한 것이다(Dunkley \& Blankstein, 2000; Dunkley et al., 2000; Fletcher et al., 2012; Weiner \& Carton, 2012). 본 척도는 총 13개 문항으로, 문항 예시로는 "일 상적으로 하는 단순한 일에 대해서도 미심쩍은 생각이 든다.”, "실수를 하면 다른 사람들이 나에 대한 평가를 낮게 할 것 같 다.", "나는 신중하게 어떤 일을 했는데도 그 일이 제대로 되지 않았다고 느낄 때가 자주 있다.” 등이 있다. 각 문항은 전혀 그 렇지 않다(1점)부터 매우 그렇다(5점)까지의 5점 리커트 척도 로 평정하도록 되어있다. 점수가 높을수록 자신을 엄격하게 감시하고, 자신의 행동을 비판적으로 평가하며, 비판에 대해 지속적으로 염려하며 완벽해지려는 성향이 높다는 것을 의미 한다. 본 연구에서 산출한 내적합치도 계수 Cronbach's $\alpha$ 는 실 수에 대한 염려가.86, 수행에 대한 의심이 .64이었다.

\section{통제변인}

본 연구에서는 통제변인으로 중학생의 성별, 학년, 학업성취 도를 연구 모형에 투입시켜 각 변인이 종속변인에 미치는 영 향을 분석하였다. 각 변인은 다음과 같이 측정하였다. 먼저 성 별은 남학생(0)을 기준변수로 하여 여학생(1)을 더미변수 처 리하였으며, 학년과 학업성취도는 연속변수로 추가하였다. 학 업성취도를 측정하기 위해 Jeon (2014)의 연구를 참고하여 성 취 수준을 상(5점)-중상-중-중하-하(1점)으로 구분한 5점 척도 를 사용하였으며, 점수가 높을수록 학업성취도가 높다는 것을 의미한다.

\section{연구절차}

본 조사는 2020년 10월 중에 군산시, 익산시, 전주시에 위치한 3 개 중학교에 재학 중인 중학생 $1,2,3$ 학년을 대상으로 하여 이루어졌으며, 온라인으로 진행되었다. 먼저 연구자가 각 학 급의 교사에게 연구목적과 절차, 예상 소요시간과 응답 시 유 의사항에 대해 설명한 후 온라인 설문 링크를 전송하였다. 이 후 교사가 설문 참여에 동의한 중학생들을 대상으로 온라인 설문 링크를 안내하고, 학생들이 해당 링크에 접속하여 자기 보고식으로 응답한 것을 설문 기간이 종료된 후 연구자가 확 인하는 방식으로 조사를 진행하였다. 한 문항이라도 응답하지 않으면 다음 문항으로 넘어가지 않는 온라인 설문의 특성상 전체 무응답이나 응답 중 발생한 결측치는 없었으나 모든 척 도에서 동일한 번호로 응답한 자료를 불성실한 답변이라고 판 단하였다. 총 542명 참여자의 응답 중 불성실한 답변인 20 명 의 자료를 제외한 후 최종적으로 522 명의 자료를 분석하였다.

\section{자료분석}

수집된 자료는 SPSS 26.0 프로그램(IBM Co., Armonk, NY)과 AMOS 26.0 프로그램(IBM Co., Armonk, NY)을 이용하여 다 음과 같은 방법으로 분석하였다. 첫째, 주요 변인들의 기술적 인 경향을 알아보고자 측정 변인 별로 평균과 표준편차를 산출 하였다. 둘째, 변인들 간의 관계를 분석하기 위하여 Pearson의 적률상관계수를 구하였다. 셋째, 연구 모형의 검증을 위하여 AMOS 26.0 프로그램을 사용하여 최대우도법 추정(maximum likelihood estimation methods)을 적용한 구조방정식 모형 (structural equation modeling)을 사용하였다. 먼저 본 연구의 잠 재변인에 해당하는 평가염려 완벽주의가 적합한 측정변인들 로 이루어져 있는지 확인하기 위해 측정모형의 확인적 요인분 석을 실시하였다. 이어서 통제변인인 중학생의 성과 학년, 학 업성취도를 투입한 구조방정식 모형 분석을 통해 연구모형의 적합성과 측정변인들의 경로계수를 확인하였다. 마지막으로, 매개효과가 통계적으로 유의한지 확인하기 위해 부트스트랩 (bootstrap) 방법을 적용하여 매개효과의 유의성을 검정하였다.

\section{Results}

\section{연구변인의 일반적 경향}

본 연구에서 측정한 중학생의 학업지연행동과 부모의 학업성 
Table 1

Means and Standard Deviations of the Variables

\begin{tabular}{lccc}
\hline \multicolumn{1}{c}{ Variables } & Mean of item score & & Kurtosis \\
\hline Academic procrastination & $(S D)$ & Skewness & -.49 \\
& 2.60 & -.14 & -.39 \\
Parental academic achievement pressure & $.43)$ & .09 & -.08 \\
Evaluative concerns perfectionism & 2.60 & -.18 & -.37 \\
Concern over mistakes & $(.52)$ & -.01 & .14 \\
Doubts about actions & 2.80 & & \\
\end{tabular}

Note. $N=522$.

Table 2

Correlation Coefficients Among the Variables

\begin{tabular}{|c|c|c|c|c|c|c|c|}
\hline Variables & 1 & 2 & 3 & 4 & 5 & $6-1$ & $6-2$ \\
\hline 1. Sex & - & & & & & & \\
\hline 2. Grade & .04 & - & & & & & \\
\hline 3. Academic achievement & -.08 & $-.12^{* *}$ & - & & & & \\
\hline 4. Academic procrastination & .20 & $.21^{* *}$ & $-.34^{* *}$ & - & & & \\
\hline 5. Parental academic achievement pressure & $-.13^{*}$ & .04 & -.03 & $.27^{* *}$ & - & & \\
\hline \multicolumn{8}{|l|}{ 6. ECP } \\
\hline 6-1. Concern over mistakes & $.16^{* *}$ & $.11^{*}$ & -.03 & $.22^{* *}$ & $.39^{* *}$ & - & \\
\hline 6-2. Doubts about actions & $.16^{* *}$ & $.15^{* *}$ & $-.15^{* *}$ & $.32^{* *}$ & $.24^{* *}$ & $.52^{* *}$ & - \\
\hline
\end{tabular}

Note. $N=522 . \mathrm{ECP}=$ Evaluative concerns perfectionism.

${ }^{*} p<.05 .{ }^{* *} p<.01$.

취압력, 평가염려 완벽주의의 가능한 점수 범위와 실제 점수범 위, 평균, 표준편차, 왜도와 첨도는 Table 1 에 제시된 바와 같다.

먼저 중학생의 학업지연행동의 평균은 2.60점이었으며 이 는 5점 척도 중, 2 점의 대체로 그렇지 않다와 3 점의 가끔 그렇 다의 중간 점수에 해당하는 값으로 본 연구에 참여한 연구 대 상의 학업지연행동 수준은 다소 낮은 편임을 알 수 있다. 다음 으로, 중학생이 지각한 부모의 학업성취압력의 평균은 2.60점 이었다. 이는 5점 척도 중, 2점의 대체로 그렇지 않다와 3점의 보통이다의 중간 점수에 해당하는 값으로 본 연구에 참여한 중 학생이 지각하는 부모의 학업성취압력 수준 또한 다소 낮은 편 이었다. 마지막으로 중학생의 평가염려 완벽주의의 평균을 하 위요인 별로 살펴보면 실수에 대한 염려가 2.73점, 수행에 대한 의심이 2.91점으로, 두 하위요인 모두 5점 척도 중, 2점의 대체 로 그렇지 않다와 3점의 보통이다의 중간점수보다 높은 수준 에 해당하고 있었다. 두 하위요인을 합산한 평가염려 완벽주의 평균 또한 2.80점으로 나타났는데, 이와 같은 경향치들은 수행 에 대한 의심 수준이 실수에 대한 염려 수준보다 약간 더 높으
나 본 연구에 참여한 중학생들의 평가염려 완벽주의 수준이 대 체적으로 보통보다 약간 낮은 수준임을 알려준다.

한편, 본 연구에서 사용한 최대우도법을 통한 구조방정 식 분석은 측정 변인의 정상분포를 기본 가정으로 하고 있기 때문에 정규성 검토를 위해 변수들의 왜도(skewness)와 첨도 (kurtosis)를 살펴보았다. 그 결과, 각 측정 변인들의 왜도와 첨 도의 절대값이 모두 1 을 넘지 않아 정규성의 가정을 만족시켜 구조방정식을 실시하는데 문제가 없음이 확인되었다.

\section{연구변인의 일반적 경향}

먼저, 중학생이 지각한 부모의 학업성취압력과 평가염려 완벽 주의가 학업지연행동에 미치는 영향을 검증하기 위하여 측정 변인들 간의 상관관계를 알아보고자 Pearson의 적률상관계수 를 산출하였다. 분석 결과는 Table 2 와 같다.

연구모형 검증에 앞서, 실수에 대한 염려, 수행에 대한 의심 이라는 2 개의 측정 변인으로 이루어진 평가염려 완벽주의의 
Table 3

Confirmatory Factor Analysis of ECP

\begin{tabular}{lcccc}
\hline & $\beta$ & $S E$ & CR & $p$ value \\
\hline ECP $\rightarrow$ Doubts about actions & .698 & .115 & 13.789 & $p<.001$ \\
ECP $\rightarrow$ Concern over mistakes & .890 & .156 & $13.560 \quad p<.001$ \\
\hline
\end{tabular}

Note. $N=522$. ECP = Evaluative concerns perfectionism.

Table 4

The Goodness of Fit Index of the Model

\begin{tabular}{cccccccc}
\hline$\chi^{2}$ & $d f$ & $p$ & $\chi^{2} / d f$ & NFI & TLI & CFI & RMSEA \\
\hline 100.04 & 52 & .00 & 1.92 & .93 & .90 & .91 & .04 \\
\hline
\end{tabular}

Table 5

Path Estimates of the Structural Model

\begin{tabular}{|c|c|c|c|c|}
\hline & $\beta$ & $S E$ & CR & $p$ value \\
\hline Grade $\rightarrow$ Academic procrastination & .13 & .04 & 3.52 & $\mathrm{p}<.001$ \\
\hline Parental academic achievement pressure $\rightarrow$ ECP & .35 & .05 & 7.88 & $\mathrm{p}<.001$ \\
\hline $\mathrm{ECP} \rightarrow$ Academic procrastination & .22 & .07 & 3.30 & $\mathrm{p}<.001$ \\
\hline
\end{tabular}

Note. $N=522$. ECP = Evaluative concerns perfectionism.

측정모형의 타당도를 검증하기 위하여 확인적 요인분석을 실 시하였다. 요인분석 결과는 Table 3에 제시되어 있다. Table 3과 같이, 평가염려 완벽주의를 구성하는 실수에 대한 염려, 수행 에 대한 의심 각각의 경로계수가 $p<.001$ 수준에서 모두 유의 미한 것으로 나타나 각 하위척도들이 평가염려 완벽주의를 유 의하게 측정하고 있는 것으로 확인되었다. 본 모형은 자유도가 0 인 포화모형으로 모형의 적합도를 확인할 필요가 없는 것으 로 나타나 별도로 모형의 적합도 지수를 확인하지 않았다(H. Kang, 2013). 위와 같은 결과에 따라, 평가염려 완벽주의의 측 정모형이 타당한 것으로 나타나 본 분석에 그대로 적용하였다.

이후 부모의 학업성취압력이 중학생의 학업지연행동에 미 치는 영향을 평가염려 완벽주의가 매개할 것이라고 가정한 연 구모형을 구조방정식을 통해 검증하였다. 먼저 연구모형의 적 합도를 살펴보았으며 그 결과는 Table 4에 제시되었다. 카이 제곱검증 결과, $\chi^{2}(52)=100.04(p<.001)$ 로 모형과 자료의 차 이가 유의한 것으로 나타났다. 즉, 본 연구에서 설정한 연구모 형을 자료가 완벽히 설명하지 못한다는 것이다. 그러나 카이 제곱검증은 복잡한 사회 현상을 간명하고 효과적으로 설명하 고자 한다는 점에서 실제 자료와 완벽히 부합하기 어려우며 (Hong, 2000) 표본의 크기가 클수록 통계적 검정력이 증가하
여 사소한 차이에도 모델을 기각할 수 있다. 따라서 카이제곱 $\left(\chi^{2}\right)$ 값뿐 아니라 표준카이자승치 $\left(\chi^{2} / d f\right)$ 와 다른 적합도 지수들 을 종합적으로 살펴볼 필요가 있다. 카이제곱 $\left(\chi^{2}\right)$ 값을 자유도 로 나눈 값인 표준카이자승치를 확인한 결과 $\chi^{2} / d f=1.92$ 였으 며, NFI, TLI, CFI가 .90 .93 사이, RMSEA가 .04로 나타나 좋 은 적합도를 보이는 것으로 확인되었다.

다음으로 부모의 학업성취압력과 중학생의 학업지연행동, 평가염려 완벽주의 간의 관계를 살펴보기 위해 경로계수를 산 출한 결과를 Table 5와 Figure 1에 제시하였다. 먼저 통제변인 으로 투입된 중학생의 성별, 학년, 학업성취도 중, 성별을 제외 한 학년과 학업성취도가 학업지연행동에 영향을 미치는 것으 로 나타났다. 구체적으로 살펴보면 학년이 높을수록 학업지연 행동을 보일 가능성이 높은 반면 $\beta=.13, p<.001)$, 학업성취 도가 높을수록 학업지연행동을 보일 가능성은 낮은 것으로 나 타났다 $(\beta=-.20, p<.001)$. 성별은 중학생의 학업지연행동에 유의한 영향을 미치지 않는 것으로 나타났다.

이어서 연구 모형의 경로계수를 살펴보면, 부모의 학업성 취압력은 자녀의 평가염려 완벽주의에 정적인 영향을 주며 $(\beta$ $=.35, p<.001)$, 학업지연행동에도 정적인 영향을 주는 것으로 나타났다 $(\beta=.19, p<.001)$. 평가염려 완벽주의 또한 중학생의 


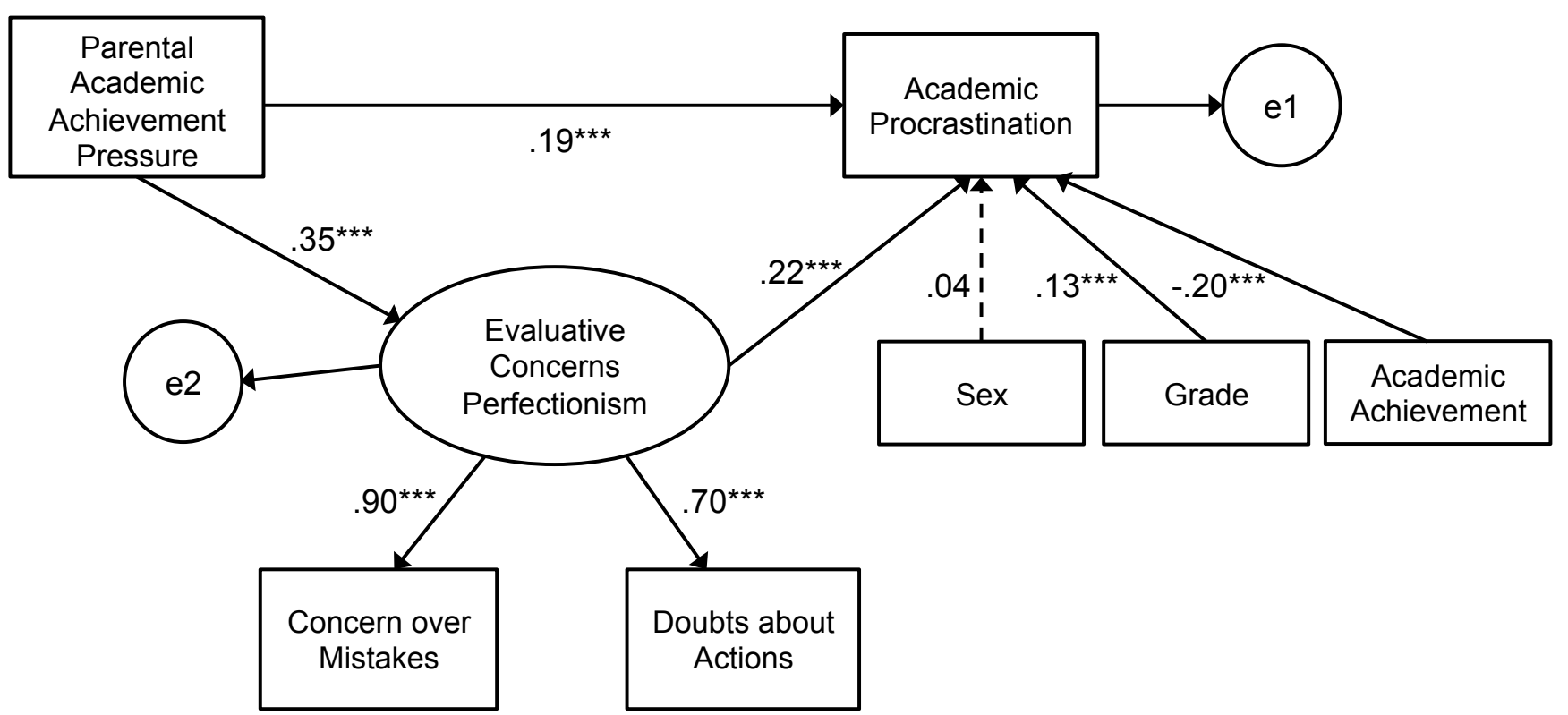

Figure 1. Evaluative concerns perfectionism as a mediator of the relationship between parental academic pressure perceived by middle school students and academic procrastination.

${ }^{* * *} p<.001$.

Table 6

Bootstrapping Result for the Mediation Effect of Evaluative Concerns Perfectionism

\begin{tabular}{lccc}
\hline & Estimate & $S E$ & $95 \%$ CI \\
\hline Evaluative concerns perfectionism & .076 & .03 & $.034 \sim .13$ \\
\hline
\end{tabular}

Note. $N=522$.

학업지연행동에 정적인 영향을 주는 것으로 나타나 $(\beta=.21$, $p<.001)$, 부모의 학업성취압력이 높을수록 자녀의 평가염려 완벽주의 수준이 높아지며, 높은 수준의 평가염려 완벽주의 경향성은 학업지연행동을 보이게 할 가능성을 증가시키는 것 으로 나타났다.

끝으로 평가염려 완벽주의의 매개효과가 통계적으로 유 의한 수준인지 검증하기 위해 부트스트랩(Bootstrap) 방법 을 적용하여 분석한 결과를 Table 6에 제시하였다, 매개효과 Estimate $(S E)$, 부트스트랩 $95 \%$ 신뢰구간 값을 분석한 결과, 평 가염려 완벽주의의 매개효과는 $95 \%$ 신뢰구간에서 상한 값과 하한 값을 보이고 있어 0 을 포함하지 않은 것으로 나타났다. 즉 평가염려 완벽주의의 매개효과는 $p<.05$ 수준에서 통계적 으로 유의하였다 $(\beta=.08, p<.05)$. 이에 따라, 부모의 학업성취 압력이 중학생의 학업지연행동에 미치는 정적 영향을 평가염 려 완벽주의가 부분매개하는 것으로 확인되었다.

\section{Discussion}

본 연구는 중학생을 대상으로 중학생이 지각한 부모의 학업 성취압력과 평가염려 완벽주의가 학업지연행동에 미치는 영 향을 알아보고 부모의 학업성취압력과 학업지연행동 간 관계 내의 평가염려 완벽주의의 매개효과를 검증하였다. 본 연구를 통해 도출된 주요 결과들과 이에 따른 시사점은 다음과 같다.

연구문제 1 과 관련하여 중학생이 지각한 부모의 학업성취 압력과 중학생의 평가염려 완벽주의가 학업지연행동에 미치 는 영향을 살펴보기 위해 성별, 학년, 이전 학업성취도를 통제 변인으로 포함하여 분석한 결과 중학생이 지각한 부모의 학업 성취압력과 중학생의 평가염려 완벽주의는 학업지연행동에 유의한 영향을 주었다. 구체적으로 중학생이 지각하는 부모의 학업성취압력 수준이 높을수록, 중학생의 평가염려 완벽주의 의 수준이 높을수록 학업지연행동을 많이 보이는 것으로 나타 났다.

먼저 중학생이 지각한 부모의 학업성취압력은 중학생의 
학업지연행동에 정적인 영향을 미치는 것으로 나타났다. 이 는 중학생이 지각하는 부모의 학업성취압력 수준이 높을수록 학업지연행동을 보일 가능성이 높고, 이와는 반대로 중학생 이 지각하는 부모의 학업성취압력 수준이 낮을수록 학업지연 행동을 보일 가능성이 낮음을 의미한다. 이는 부모의 학업성 취압력이 자녀의 학업지연행동에 유의하게 정적인 영향을 미 치며(H.-Y. Ahn \& Han, 2019; Ferrari \& Olivette, 1994), 부모의 통제적이고 권위적인 양육태도 또한 학업지연행동에 정적인 영향을 미쳤다는 선행연구들과 일치하는 결과이다(Soysa \& Weiss, 2014; Won \& Shirley, 2018). 더 나아가 이러한 결과는 지 연행동이 지나치게 엄격하거나 권위적인 부모에게서 자녀가 자율성을 추구하는 방식으로 저항하고 회피하는 수단이 되며 부모의 지나친 압력과 통제에 대한 수동공격적인 방법으로 학 습자들이 지연행동을 보인다는 선행연구자들의 주장들을 토 대로 해석해볼 수 있다(Flett, Hewitt, \& Martin, 1995). 부모는 자녀에게 높은 수준의 학업성취를 기대하고 요구하며 학업과 관련된 행동을 통제하고 관리할 때 자녀가 시간을 효율적으로 운용하여 더 나은 성취를 보일 것이라고 생각할 수 있지만, 본 연구결과는 이러한 부모의 양육태도를 자녀가 과도하게 인식 할수록 학업 상황에서 지연행동을 보이고 결국 성취에까지 악 영향을 미칠 수 있음을 시사하고 있다.

이와는 반대로, 몇몇 선행 연구는 본 연구에서의 학업성취 압력과는 반대 양상의 양육태도인 자녀의 자율성을 존중하는 부모의 양육태도가 학생들의 학업지연행동에 유의하게 부적 영향을 미친다는 것을 보고하였다(Steel, 2007; Won \& Shirley, 2018). 뿐만 아니라 적절한 수준의 부모의 기대는 자녀의 학업 성취에 긍정적 영향을 미치고 있었다(Choo \& Lim, 2008). 이 를 종합하면, 부모들이 자녀에게 학업 상황에서 자율적인 선 택권을 주고, 적절한 수준의 기대와 지지, 도움을 제공하며, 부 모의 양육행동과 결정에 대한 근거를 제시함으로써 자녀의 학 업지연행동을 예방하고 자기조절학습 능력을 기르도록 도울 수 있을 것이다. 더 나아가 학생이 학업에 대한 내재적 동기를 가질 수 있도록 돕는 것은 지연행동을 예방하고 더 나은 성취 를 이루는데 도움이 될 수 있다. Deci와 Ryan (2002)에 따르면, 오로지 부모가 기대하는 성취 기준에 따라 자녀를 통제하는 양육태도는 내재적 동기를 손상시키고 자녀가 성취를 통해 진 정으로 이루고자 하는 바를 알아차리지 못하게 만든다고 하였 다. 즉, 자녀들이 부모의 개입에 따라 학업 성취 기준을 세우는 것이 아닌, 학업 수행 과정에 집중하면서 그 안에서 스스로 즐 거움을 얻는 것 자체가 성취의 동기가 될 수 있도록 하는 것이 더욱 중요하다는 것이다(Ryan \& Connell, 1989). 결론적으로
부모의 학업성취압력을 과도하다고 지각하고 있으며 학업지 연행동을 보이는 중학생의 경우, 부모가 학업 성취에 과잉간 섭하지 않으며 학생 스스로 학업에 대한 목표를 설정하고, 이 를 달성하는 과정을 존중해주는 것이 필요하다고 볼 수 있다.

다음으로 중학생의 평가염려 완벽주의가 학업지연행동에 미치는 영향을 살펴본 결과, 평가염려 완벽주의는 학업지연 행동에 정적인 영향을 미치는 것으로 나타났다. 이는 평가염 려 완벽주의와 같은 부적응적 완벽주의의 특성이 학업지연행 동을 예측한다는 다수의 연구결과들과 맥락을 함께하는 것이 라 볼 수 있다(Bong et al., 2014; S.-G. Kim \& Park, 2018; Ozer et al., 2014). 평가염려 완벽주의의 수준이 높은 학습자는 자신 의 수행과 실수에 대해 끈임없이 염려하며 타인의 비난을 받 게 될 수도 있다는 심리적 부담감과 같은 부정적 정서를 갖게 된다. 이에 따라 수행의 실패는 곧 자신의 무능력함을 드러내 는 일이라고 생각하여 학업 수행을 선택하기 보다는 회피하는 행동을 보일 수 있다(Han, 2011; B. R. Park \& Yang, 2012). 다시 말해 이들은 학업 수행의 결과에 대하여 성공보다는 실패 확 률이 더 높다고 지각하여 이에 따른 부정적 정서를 느끼고, 타 인에게 자신이 실패하는 모습을 보이기보다는 과제를 회피하 는 전략을 사용함으로써 자신의 자존감을 지키고자 할 수 있 다는 것이다. 이 결과는 중학생이 가지고 있는 평가염려 완벽 주의에 개입하는 것이 학업지연행동을 예방하고 중재하기 위 한 또 하나의 방안이 될 수 있음을 시사한다.

다수의 연구자들은 평가염려 완벽주의가 가지고 있는 자기 비난적인 특성과 평가에 대한 우려, 이상적 자기와 현실적 자 기의 차이를 의미하는 불일치에 대한 인식이 부적응과 관련이 있는 완벽주의의 핵심적인 속성임을 주장하였다(Blankstein, Dunkley, \& Wilson, 2008; Dunkley et al., 2000). 이러한 연구자 들의 의견을 근거로 하여 평가염려 완벽주의에 개입할 때 위 의 특성을 고려할 필요성이 제기된다. 먼저 자기비난적이고 평가에 대한 우려를 하고 있는 학생들을 대상으로는 이야기치 료(narrative therapy)를 진행해볼 수 있을 것이다. 이야기치료 는 문제를 외재화시키고 문제에서 벗어났던 예외 상황을 파악 하여 긍정적인 시각에서 대안적인 이야기를 형성하도록 돕는 상담 기법이다(H. K. Kim, 2010). 구체적으로, 학생들로 하여 금 평가에 대해 조금이라도 덜 민감했고, 자신을 조금이라도 칭찬해볼 수 있었던 과거의 예외 경험을 반추시킴으로써 부적 응적인 완벽주의의 시각에서 벗어나 긍정적인 정체감을 형성 하도록 도울 수 있을 것이다. 다음으로 불일치에 대한 인식은 평가염려 완벽주의자들이 지닌 비현실적이고 높은 기준을 낮 추도록 도움으로써 개입할 수 있을 것이다. 예를 들면, 인지행 
동치료 등을 통해 자신이 현재 추구하고 있는 기준이 달성하 기에는 비합리적인 목표임을 깨닫게 해줌으로써 기준 자체를 현실적인 수준으로 수정할 수 있게 도울 수 있을 것이다(Jeong \& Lee, 2013).

한편, Hewitt과 Flett (1991)은 다차원적 완벽주의 성향 중 자신에 대한 높은 기준을 설정하고 행동을 엄격하게 평가, 점 검하며 완벽에 도달하기 위해서 노력해야 한다고 지각하는 특 성인 자기지향적 완벽주의 성향을 가진 개인들은 자신의 내적 동기에 따라 완벽해지고자 하는 목표를 성취하려는 경향성이 있다고 언급하였다. 이는 완벽주의 내에서도 개인의 행동을 동기화 시키는 적응적인 기능이 있음을 시사하는 것이라고 볼 수 있다. 실제로, 자기지향적 완벽주의와 지연행동 간 관계를 탐색한 선행연구들은 자기지향적 완벽주의가 오히려 성취동 기를 높이고 지연행동을 낮추는데 기여할 수 있음을 보고하였 다(Capan, 2010; Han, 2011; Seo, 2008). 즉 완벽한 수행을 지향 하더라도 스스로 그 기준을 성취하기 위해 적극적으로 노력한 다면 지연행동으로 이어지지 않지만 이러한 기준에 도달하기 위한 본질적인 동기와 자기결심이 부족한 개인들은 지연행동 이 나타날 수 있다는 것이다. 이러한 연구결과들을 고려해볼 때, 평가염려 완벽주의와 같은 부적응적 완벽주의를 가진 학 생들을 대상으로 성취를 향한 내적 동기를 함양시킬 수 있는 프로그램 등에 참여할 수 있도록 한다면 학업지연행동을 줄이 는데 도움을 줄 수 있을 것이다.

또한 완벽주의와 관련된 여러 선행연구에 따르면 '완벽해 지고자 하는 노력'에서 '완벽주의적인 염려'와 중첩되는 특성 을 통계적으로 통제한 결과, '완벽해지고자 하는 노력' 자체는 적응적 행동과 정적으로 연관되고 부적응적 행동과는 부적으 로 연관됨이 밝혀졌다(Hill, Huelsman, \& Araujo, 2010; Stoeber \& Otto, 2006; Xie et al., 2018). 이는 완벽주의적인 염려의 특 성이 완벽해지고자 하는 노력의 적응적인 특성을 상쇄시킬 수 있음을 시사한다고 볼 수 있다. 이를 본 연구의 개입방안에 적 용하면, 중학생의 평가염려 완벽주의에 개입할 때 해당 성향 을 단번에 변화시키기는 어려우므로 완벽주의적인 염려보다 는 완벽해지고자 하는 노력의 특성에 초점을 맞출 수 있도록 돕고, 이를 성취의 동기로서 기능하게 한다면 학업지연행동을 감소시키는데 도움을 줄 수 있을 것이다.

한편, 연구문제 2 와 관련하여 본 연구는 중학생이 지각한 부모의 학업성취압력이 학업지연행동에 미치는 영향에서 평 가염려 완벽주의가 매개효과를 가지는지 검증하였다. 그 결 과, 부모의 학업성취압력이 중학생의 학업지연행동에 미치는 영향을 평가염려 완벽주의가 부분매개하는 것으로 확인되었
다. 이는 위에 언급하였던 부모의 학업성취압력과 평가염려 완벽주의가 학업지연행동에 직접적인 영향을 미치는 것 외에 도 부모의 학업성취압력이 중학생의 평가염려 완벽주의를 높 이고, 그 결과로 학업지연행동을 경험할 가능성이 크다는 것 을 의미한다.

이를 더욱 자세히 살펴보면, 먼저 부모의 학업성취압력은 평가염려 완벽주의에 정적인 영향을 미치는 것으로 나타났다. 이와 같은 연구결과는 부모의 학업성취압력과 같이 통제적이 고 권위적인 양육태도가 자녀의 완벽주의의 형성에 영향을 미 친다는 선행연구들을 지지하는 결과이다(Fletcher et al., 2012; Miller et al., 2012). 즉 부모의 과도한 기대를 지각하고 있는 자 녀는 부모에게 좋은 평가를 받지 못할 것이 예상되어 자신을 비하하며, 자신의 능력이 평가되는 과정 속에서 끊임없이 부 담을 느끼는 평가염려 완벽주의를 갖게 될 수 있다는 것이다. 이는 청소년들이 부모와의 관계를 통해 그들이 어떤 존재인 지, 타인에게 어떤 방식으로 자신을 나타내야하는지, 또는 어 떤 존재가 되어야하는지에 대한 인식을 형성하고, 부모의 높 은 기대를 자녀가 인식하는 것이 완벽주의의 중요한 요인이 라는 선행연구들(Becht et al., 2017; Hibbard \& Walton, 2014)과 맥락을 같이한다고 볼 수 있다.

또한 본 연구 결과는 자기결정이론과도 다시금 연결 지어 해석해볼 수 있다. 본 이론은 개인의 자율적 행동 및 자기조절 능력에 대한 내재적 동기의 중요성을 강조하는 이론으로, 개 인이 유능성, 친밀성, 자율성의 기본적 심리적 욕구를 충족 받 을 수 있는 사회적 환경에 존재하게 된다면 내재적 동기가 극 대화되어 성취를 이룰 수 있지만 이를 저해하는 환경에 존재 하게 되면 개인의 성장 및 안녕에 여러 부정적 결과가 초래된 다고 설명한다(Deci \& Ryan, 2000, 2002), 즉 학업 성취 기대에 대한 부모의 압력은 학생들이 부모의 기대를 충족시키지 못했 다는 인식을 갖게 만들고, 자율성과 유능성과 같은 기본적 심 리적 욕구를 충족시킬 수 있는 기회를 감소시키는 사회적 환 경으로 작용할 수 있다. 그 결과, 비현실적으로 높은 부모의 기 준을 일부 내면화했음에도 그것을 완전히 자신의 것으로 채택 하지 않아 평가염려 완벽주의와 같은 자율적이지 못한 동기 상태를 지니게 되고, 이에 따른 부정적 결과로 학업지연행동 을 보이게 될 수 있다.

이상과 같이 본 연구에서는 부모의 학업성취압력이 중학교 청소년의 학업지연행동에 미치는 직접적인 영향뿐 아니라 부 모의 학업성취압력이 중학생의 평가염려 완벽주의를 통해 학 업지연행동에 영향을 미치는 간접효과가 유의하게 나타나 평 가염려 완벽주의가 매개변인으로 작용하는 것을 확인하였다. 
이처럼 부모 학업성취압력을 높게 지각할수록 더 높은 수준의 평가염려 완벽주의를 내면화하며, 자신의 행동에 대한 지나친 비판과 함께 타인의 비판에 대해 지속적으로 신경을 쓰는 인 지신념을 가진 중학생은 결과적으로 학업 상황에서 지연행동 을 보일 가능성이 높다. 즉 학업지연행동은 부모의 학업성취 압력과 같은 환경적 요인 뿐 아니라 중학생의 평가염려 완벽 주의와 같은 개인 내적 요인이 복합적으로 작용하여 발생하는 행동임을 지지하는 연구결과라고 볼 수 있다.

한편, 본 연구에서 통제변인으로 투입한 중학생의 성별, 학 년, 학업성취도 중 학년과 학업성취도 변인이 학업지연행동 에 유의미한 영향을 미치는 것으로 나타났다. 우선, 학년은 학 업지연행동에 정적인 영향을 미치는 것으로 나타났는데, 이 는 학년이 높아질수록 학업지연행동을 보일 가능성이 증가된 다는 선행연구 결과와 일치한다(Rosário et al., 2009). 반면, 학 업성취도는 학업지연행동에 부적인 영향을 미치는 것으로 나 타났는데, 이는 학업성취도가 높을수록 학업지연행동을 덜 보 이게 된다는 선행연구와 일치하는 결과이다(Sæle et al., 2017; Steel, 2007). 이러한 결과의 이유는 다양하겠지만, 보통 학년이 높고 학업성취도가 낮은 집단의 학생들이 학업 난이도를 높게 체감하여 과제 혐오감, 시간 관리 능력의 부족 등을 경험할 가 능성이 증가되기 때문일 것으로 해석해볼 수 있다. 따라서 중 학생의 학업지연행동을 경감시킴에 있어서 학년과 학업성취 도와 같은 학습자 개인이 가진 특성에 따라 차별화된 개입을 할 필요성이 추가로 요구된다.

마지막으로 본 연구의 제한점을 토대로 후속연구를 위한 제언을 하면 다음과 같다. 첫째, 본 연구에서는 평가염려 완벽 주의의 개념을 측정하기 위해 FMPS의 하위요인 중 '실수에 대 한 염려', ‘수행에 대한 의심' 차원을 측정하였는데, 이는 선행 연구들에 근거한 것이다(Dunkley \& Blankstein, 2000; Dunkley et al., 2000; Fletcher et al., 2012; Weiner \& Carton, 2012). 그러 나 다차원적 완벽주의의 특성에 따라, 이와 같은 하위차원들 이 완벽주의의 부적응적, 적응적 속성을 얼마나 대표할 수 있 는가에 대한 의문은 여전히 남아있다는 주장이 제기되고 있 다(Wimberley \& Stasio, 2013). 따라서 완벽주의를 측정하는 다 양한 척도를 함께 사용하여 완벽주의의 부적응적 속성을 더 욱 체계적으로 반영하는 측정 방안을 고안하고, 더욱 명확하 게 측정할 필요가 있다. 대표적으로, Slaney 등(2001)에 의해 개 발된 완벽성향 척도 개정판(Almost Perfectionism Scale-Revised [APS-R]) 내의 하위요인인 '불일치' 경우, 완벽주의자의 정서 적 불편감을 설명하는데 중요한 것으로 알려진 실제적 자기와 이상적 자기 또는 의무적 자기 간의 괴리에 관한 내용을 측정
함으로써 완벽주의의 부적응적 측면을 잘 대변할 수 있는 하 위요인으로 기능할 수 있을 것이다(Jeong \& Lee, 2013).

둘째, 일부 선행연구는 부모의 성취압력과 학업지연행동 간 유의한 관계가 없으며 오히려 학업성취에 도움을 줄 수도 있다는 결과를 보고하고 있다(Choo \& Lim, 2008; S.-Y. Lee et al., 2016). 본 연구에서 측정하고 있는 부모의 학업성취압력 또한 자녀로 하여금 학업에 관한 적절한 수준의 긴장상태와 스트레스를 유발하여 오히려 지연행동을 감소시킬 가능성을 배제할 수 없다. 따라서 부모의 학업성취압력과 학업지연행동 간 관계가 계속해서 선형적으로 나타나는지, 혹은 다른 양상 의 관계를 보이게 될 수도 있는지에 관한 후속 연구가 추가로 수행될 필요성이 있다.

셋째, 본 연구에서는 중학생이 지각한 부모의 학업성취압 력, 평가염려 완벽주의, 학업지연행동에 대해 모두 자기보고 식으로 응답하게 하였다. 이는 부모의 양육태도는 부모의 주 관적인 판단보다는 자녀가 지각하고 해석하는 방식에 따라 다르게 평가될 수 있다는 선행연구자들의 주장(E. B. Ahn \& Kim, 2020; Soysa \& Weiss, 2014)과 평가염려 완벽주의와 학업 지연행동이 모두 학습자 개인이 가지고 있는 내적 신념과 행 동이라는 점에 근거한 것이다. 그러나 연구대상이 사회적으로 바람직한 모습을 보이려는 경향으로 응답했을 가능성 또한 배 제할 수 없기 때문에, 학업 상황에서 제 3 자에 의한 평정도구나 사회적 바람직성을 평가하는 도구를 활용하는 등 다양한 측정 방법을 고려하여 보다 객관적인 응답치를 얻을 필요가 있다.

넷째, 본 연구의 대상은 군산시, 익산시, 전주시에 위치한 3 개의 중학교에서 편의표집한 것으로 연구결과를 해석하고 일 반화하는데 있어서 유의할 필요가 있다. 본 연구의 연구대상 은 교육열이 높은 수도권에 비해 상대적으로 낮은 지방에서 표집되었는데, 이러한 지역적 특성이 연구 결과에 영향을 미 쳤을 가능성이 있다. 따라서 표본의 크기를 더욱 확대하고 전 국 단위의 표집 방법을 사용한 후속 연구를 통해 연구 결과의 일반화 가능성을 검증할 필요가 있을 것이다.

위와 같은 제한점에도 불구하고 본 연구의 의의는 다음과 같다. 첫째, 지연행동은 수행 상황에서 요구되는 성취 기준을 충족시키지 못할 것이라는 두려움에 의해 발생하는 부적응 행 동임에도 불구하고, 기존의 연구들이 살펴본 부모의 양육태 도는 이러한 특성을 타당하게 측정하지 못하였다. 그러나 본 연구는 위와 같은 특성을 측정할 수 있는 학업성취압력이 학 업지연행동에 미치는 영향을 살펴봄으로써 두 변인 간 관계 를 명확히 하고 기존 연구의 제한점을 보완하였다는 데 의의 가 있다. 또한 이를 토대로 학업지연행동을 감소시킬 수 있는 
교육 환경의 조성을 위해서는 학업성취에 대한 부모의 기대나 지지가 주어지는 적절한 방식의 중요성을 강조할 수 있다는 점에서 시사점을 가진다.

둘째, 학업지연행동의 선행요인으로 학습자를 둘러싸고 있 는 부모 양육태도와 같은 환경적 요인과 완벽주의와 같은 개 인 내적 요인을 함께 고려함으로써 학업지연행동을 감소시키 기 위한 방안에 도움이 될 수 있다는 점에서 의의가 있다. 본 연 구의 결과를 종합해보면, 중학생 자녀의 학업지연행동을 감소 시키기 위해서는 부모들이 자녀에게 학업 상황에서 자율적인 선택권을 주고, 과잉간섭하지 않아야 할 뿐 아니라 완벽주의와 같은 개인의 인지적 신념이 형성된 원인을 탐색하고 이에 대한 개입이 함께 이루어져야 할 필요성을 시사한다. 즉, 본 연구 결 과를 통해 중학생의 학업지연행동에 가정 환경적 요인과 개인 내적 요인이 통합적으로 영향을 미친다는 것을 확인하였고 이 를 토대로 현재 진행되고 있는 다양한 개입 프로그램을 수정 및 보완하여야 함을 시사하였다는 점에서 의의가 있다.

\section{Notes}

This article is part of the first author's master's thesis submitted in 2021, and this article was presented as a poster at the 2021 Annual Spring Conference of the Korean Association of Child Studies.

\section{Conflict of Interest}

No potential conflict of interest relevant to this article was reported.

\section{References}

\section{In English}

Bandura, A. (1999). Social cognitive theory: An agentic perspective. Asian Journal of Social Psychology, 2(1), 21-41. doi:10.1111/1467839X.00024

Becht, A. I., Nelemans, S. A., van Dijk, M. P. A., Branje, S. J. T., van Lier, P. A. C., Denissen, J. J. A., \& Meeus, W. H. J. (2017). Clear self, better relationships: Adolescents' selfconcept clarity and relationship quality with parents and peers across 5 years. Child Development, 88(6), 1823-1833. doi:10.1111/cdev.12921

Blankstein, K. R., Dunkley, D. M., \& Wilson, J. (2008). Evaluative concerns and personal standards perfectionism: Self-esteem as a mediator and moderator of relations with personal and academic needs and estimated GPA. Current Psychology, 27, 29-61. doi:10.1007/s12144-008-9022-1

Bong, M., Hwang, A., Noh, A., \& Kim, S. I. (2014). Perfectionism and motivation of adolescents in academic contexts. Journal of Educational Psychology, 106(3), 711-729. doi:10.1037/ a0035836

Burnam, A., Komarraju, M., Hamel, R., \& Nadler, D. R. (2014). Do adaptive perfectionism and self-determined motivation reduce academic procrastination? Learning and Individual Differences, 36, 165-172. doi:10.1016/j.lindif.2014.10.009

Çapan, B. E. (2010). Relationship among perfectionism, academic procrastination and life satisfaction of university students. Procedia-Social and Behavioral Sciences, 5, 1665-1671. doi:10. 1016/j.sbspro.2010.07.342

Cerino, E. S. (2014). Relationships between academic motivation, self-efficacy, and academic procrastination. Psi Chi Journal of Psychological Research, 19(4), doi:10.24839/2164-8204. JN19.4.156

Closson, L. M., \& Boutilier, R. R. (2017). Perfectionism, academic engagement, and procrastination among undergraduates: The moderating role of honors student status. Learning and Individual Differences, 57, 157-162. doi:10.1016/ j.lindif.2017. 04.010

Deci, E. L., Eghrari, H., Patrick, B. C., \& Leone, D. R. (1994). Facilitating internalization: The self-determination theory perspective. Journal of Personality, 62(1), 119-142. doi:10.1111/j.1467-6494.1994.tb00797.x

Deci, E. L., \& Ryan, R. M. (2000). The "what" and "why" of goal pursuits: Human needs and the self-determination of behavior. Psychological Inquiry, 11(4), 227-268. doi:10. 1207/S15327965PLI1104_01

Deci, E. L., \& Ryan, R. M. (2002). The paradox of achievement: The harder you push, the worse it gets. In J. Aronson (Ed.), Improving academic achievement: Impact of Psychological Factors on Education (pp. 61-87). New York: Academic Press.

Díaz-Morales, J. F., Cohen, J. R., \& Ferrari, J. R. (2008). An integrated view of personality styles related to avoidant procrastination. Personality and Individual Differences, 45(6), 554-558. doi:10.1016/j.paid.2008.06.018

Dunkley, D. M., \& Blankstein, K. R. (2000). Self-critical perfectionism, coping, hassles, and current distress: A structural equation modeling approach. Cognitive Therapy and Research, 24(6), 713-730. doi:10.1023/a:1005543529245

Dunkley, D. M., Blankstein, K. R., Halsall, J., Williams, M., \& Winkworth, G. (2000). The relation between perfectionism and distress: Hassles, coping, and perceived social support as mediators and moderators. Journal of Counseling Psychology, 47(4), 437-453. doi:10.1037/0022- 
0167.47.4.437

Ellis, A., \& Knaus, W. J. (1979). Overcoming procrastination: Or how to think and act rationally in spite of life's inevitable hassles. New York: Signet.

Ferrari, J. R., \& Olivette, M. J. (1994). Parental authority and the development of female dysfunctional procrastination. Journal of Research in Personality, 28(1), 87-100. doi:10.1006/ jrpe.1994.1008

Fletcher, K. L., Shim, S. S., \& Wang, C. (2012). Perfectionistic concerns mediate the relationship between psychologically controlling parenting and achievement goal orientations. Personality and Individual Differences, 52(8), 876-881. doi:10.1016/j.paid.2012.02.001

Flett, G. L., Hewitt, P. L., \& Martin, T. R. (1995). Dimensions of perfectionism and procrastination. In J. R. Ferrari, J. L. Johnson, \& W. G. McCown. Procrastination and task avoidance: Theory, research, and treatment (pp. 113-136). New York: Springer.

Hamachek, D. E. (1978). Psychodynamics of normal and neurotic perfectionism. Psychology: A Journal of Human Behavior, 15(1), 27-33.

Hashemi, L., \& Latifian, M. (2014). Test anxiety as a mediator between perfectionism and academic procrastination. Journal of Teaching and Education, 3(3), 509-520.

Hewitt, P. L., \& Flett, G. L. (1991). Perfectionism in the self and social contexts: Conceptualization, assessment, and association with psychopathology. Journal of Personality and Social Psychology, 60(3), 456. doi:10.1037/00223514.60.3.456

Hibbard, D. R., \& Walton, G. E. (2014). Exploring the development of perfectionism: The influence of parenting style and gender. Social Behavior and Personality: An International Journal, 42(2), 269-278. doi:10.2224/ sbp.2014.42.2.269

Hill, R. W., Huelsman, T. J., \& Araujo, G. (2010). Perfectionistic concerns suppress associations between perfectionistic strivings and positive life outcomes. Personality and Individual Differences, 48(5), 584-589. doi:10.1016/j.paid. 2009.12.011

Katz, I., Eilot, K., \& Nevo, N. (2014). "I'll do it later": Type of motivation, self-efficacy and homework procrastination. Motivation and Emotion, 38(1), 111-119. doi:10.1007/ s11031-013-9366-1

Lay, C. H., \& Schouwenburg, H. C. (1993). Trait procrastination, time management, and academic behavior. Journal of Social Behavior and Personality, 8(4), 647-662.

Milgram, N., \& Tenne, R. (2000). Personality correlates of decisional and task avoidant procrastination. European Journal of Personality, 14(2), 141-156. doi:10.1002/(SICI)10990984(200003/04)14:2<141::AID-PER369 > 3.0.CO;2-V
Milgram, N., \& Toubiana, Y. (1999). Academic anxiety, academic procrastination, and parental involvement in students and their parents. British Journal of Educational Psychology, 69(3), 345-361. doi:10.1348/000709999157761

Miller, A. L., Lambert, A. D., \& Speirs Neumeister, K. L. (2012). Parenting style, perfectionism, and creativity in highability and high-achieving young adults. Journal for the Education of the Gifted, 35(4), 344-365. doi:10.1177/ 0162353212459257

Ozer, B. U., O’Callaghan, J., Bokszczanin, A., Ederer, E., \& Essau, C. (2014). Dynamic interplay of depression, perfectionism and self-regulation on procrastination. British Journal of Guidance \& Counselling, 42(3), 309-319. doi:10.1080/030 69885.2014.896454

Rosário, P., Costa, M., Núñez Pérez, J. C., González-Pienda, J. A., Solano Pizarro, P., \& Valle, A. (2009). Academic procrastination: Associations with personal, school, and family variables. The Spanish Journal of Psychology, 12(1), 118-127, doi:10.1017/s1138741600001530

Ryan, R. M., \& Connell, J. P. (1989). Perceived locus of causality and internalization: Examining reasons for acting in two domains. Journal of Personality and Social Psychology, 57(5), 749. doi:10.1037/0022-3514.57.5.749

Sæle, R. G., Dahl, T. I., Sørlie, T., \& Friborg, O. (2017). Relationships between learning approach, procrastination and academic achievement amongst first-year university students. Higher Education, 74, 757-774. doi:10.1007/ s10734-016-0075-z

Seo, E. H. (2008). Self-efficacy as a mediator in the relationship between self-oriented perfectionism and academic procrastination. Social Behavior and Personality: An International Journal, 36(6), 753-764. doi:10.2224/sbp.2008.36.6.753

Slaney, R. B., Rice, K. G., Mobley, M., Trippi, J., \& Ashby, J. S. (2001). The revised almost perfect scale. Measurement and Evaluation in Counseling and Development, 34(3), 130-145. doi:10.1080/07481756.2002.12069030

Solomon, L. J., \& Rothblum, E. D. (1984). Academic procrastination: Frequency and cognitive-behavioral correlates. Journal of Counseling Psychology, 31(4), 503-509. doi:10.1037/00220167.31.4.503

Soysa, C. K., \& Weiss, A. (2014). Mediating perceived parenting styles-test anxiety relationships: Academic procrastination and maladaptive perfectionism. Learning and Individual Differences, 34, 77-85. doi:10.1016/j.lindif.2014.05.004

Spada, M. M., Hiou, K., \& Nikcevic, A. V. (2006). Metacognitions, emotions, and procrastination. Journal of Cognitive Psychotherapy, 20(3), 319-326. doi:10.1891/jcop.20.3.319

Steel, P. (2007). The nature of procrastination: A meta-analytic and theoretical review of quintessential self-regulatory failure. Psychological Bulletin, 133(1), 65-94. doi:10.1037/0033- 
2909.133.1.65

Steel, P., Brothen, T., \& Wambach, C. (2001). Procrastination and personality, performance, and mood. Personality and Individual Differences, 30(1), 95-106. doi:10.1016/S01918869(00)00013-1

Steel, P., \& Klingsieck, K. B. (2016). Academic procrastination: Psychological antecedents revisited. Australian Psychologist, 51(1), 36-46. doi:10.1111/ap.12173

Stoeber, J., \& Otto, K. (2006). Positive conceptions of perfectionism: Approaches, evidence, challenges. Personality and Social Psychology Review, 10(4), 295-319. doi:10.1207/s15327957 pspr1004_2

Tice, D. M., \& Baumeister, R. F. (1997). Longitudinal study of procrastination, performance, stress, and health: The costs and benefits of dawdling. Psychological Science, 8(6), 454458. doi:10.1111/j.1467-9280.1997.tb00460.x

Vansteenkiste, M., Lens, W., \& Deci, E. L. (2006). Intrinsic versus extrinsic goal contents in self-determination theory: Another look at the quality of academic motivation. Educational Psychologist, 41(1), 19-31. doi:10.1207/s15326985ep4101_4

Weiner, B. A., \& Carton, J. S. (2012). Avoidant coping: A mediator of maladaptive perfectionism and test anxiety. Personality and Individual Differences, 52(5), 632-636. doi:10.1016/j.paid.2011.12.009

Wimberley, T. E., \& Stasio, M. J. (2013). Perfectionistic thoughts, personal standards, and evaluative concerns: Further investigating relationships to psychological distress. Cognitive Therapy and Research, 37, 277-283. doi:10.1007/s10608012-9462-7

Won, S., \& Shirley, L. Y. (2018). Relations of perceived parental autonomy support and control with adolescents' academic time management and procrastination. Learning and Individual Differences, 61, 205-215. doi:10.1016/j.lindif. 2017.12.001

Xie, Y., Yang, J., \& Chen, F. (2018). Procrastination and multidimensional perfectionism: A meta-analysis of main, mediating, and moderating effects. Social Behavior and Personality: An International Journal, 46(3), 395-408. doi: $10.2224 /$ sbp. 6680

Zakeri, H., Esfahani, B. N., \& Razmjoee, M. (2013). Parenting styles and academic procrastination. Procedia-Social and Behavioral Sciences, 84(9), 57-60. doi:10.1016/ j.sbspro.2013.06.509

\section{In Korean}

Ahn, E. B., \& Kim, H. H. (2020). The influence of mother's rational parenting behavior on academic procrastination of middle school students: Effect of mediated moderation of self-control through intrinsic motivation. Korean Journal of Child Studies, 41(2), 15-25. doi:10.5723/kjcs.2020.41.2.15

Ahn, H.-Y., \& Han, Y.-J. (2019). The moderating effects of ego-resilience on the relationships between academic achievement pressure and academic procrastination. The Journal of Play Therapy, 23(3), 29-42. doi:10.32821/ JPT.23.3.3

Baek, J., \& Lee, S. (2016). A study on the relationship between perceived parental psychological control and academic procrastination of middle school students: The mediating effects of socially prescribed perfectionism and fear of failure. The Korean Journal of School Psychology, 13(1), 99122.

Choo, S. Y., \& Lim, S. M. (2008). The relationship between parental achievement pressure and high school students' academic achievements: The mediating effects of parental involvement and academic self-efficacy, and the moderating effect of academic procrastination. Studies on Korean Youth, 19(4), 169-198.

Chung, S. J. (1999). A study of the development of cognitive-behavioral group counseling program for reducing the perfectionism (Doctoral dissertation). Retrived from http://www.riss.kr/ link?id=T7726088

Han, Y.-S. (2011). The effects of perfectionism, self-efficacy, and fear of failure on procrastination. Korean Journal of Youth Studies, 18(4), 277-299.

Hong, S. (2000). The criteria for selecting appropriate fit indices in structural equation modeling and their rationale. Korean Journal of Clinical Psychology, 19(1), 161-177.

Jeon, S. M. (2014). The effects of high school students' perfectionism on their academic procrastination: The moderating role of academic self-efficacy (Doctoral dissertation). Retrived from http://www.riss.kr/link?id=T13571984

Jeong, S.-M., \& Lee, D.-G. (2013). Differences in passive/active procrastination, happiness, and depression by the clusters of perfectionism in college students. Korean Journal of Counseling, 14(2), 857-875.

Kang, H. (2013). Discussions on the suitable interpretation of model fit indices and the strategies to fit model in structural equation modeling. Journal of the Korean Data Analysis Society, 15(2), 653-668.

Kang, Y. C. (2003). On the relationship among the parents' academic achievement pressure recognized by the elementary pupils, their academic self and their attitude toward it (Doctoral dissertation). Retrived from http://www.riss.kr/link?id=T9153393

Kim, H. K. (2010). The development and validation of a narrative therapy program for school maladjusted youth. The Korean Journal of Counseling and Psychotherapy, 22(2), 329-349.

Kim, N.-K., \& Han, G. B. (2019). The relationship between perceived parental psychological control and academic 
procrastination of middle school students: The mediating roles of socially prescribed perfectionism and self-esteem. Korean Journal of Youth Studies, 26(2), 255-280.

Kim, S.-G,, \& Park, E.-Y. (2018). The relationship between evaluative concerns perfectionism and academic procrastination of university students: The mediating effect of shame and maladaptive cognitive emotion regulation. The Korean Journal of School Psychology, 15(3), 287-306. doi:10.16983/kjsp.2018.15.3.287

Lazarus, R. S., \& Folkman, S. (2001). Stress, appraisal, and coping (J. Kim, Trans.). Seoul: Daekwang Press. (Original wark published 1984)

Lee, S.-Y., Kim, S., \& Bong, M. (2016). Investigation into the dispositional, environmental, and motivational antecedents of academic procrastination. The Korean Journal of Educational Psychology, 30(3), 635-669.

Lee, Y., \& Joeng, J. R. (2016). The mediating effect of socially prescribed perfectionism on the relation between parental pressure for academic achievement and test anxiety among high school students. Asian Journal of Education, 17(2), 103-126.

Park, B. R., \& Yang, N. M. (2012). The relationship between socially prescribed perfectionism and academic procrastination of university students: The mediating effect of performanceavoidance achievement goal orientation and self-handicapping strategy. Korean Journal of Psychology: General, 31(2), 541-561.
Park, H., \& Lee, S.-Y. (2020). Effects of parental psychological control on academic procrastination: The sequential mediating effects of maladaptive perfectionism and self-regulated learning. The Korean Journal of Educational Psychology, 34(2), 327-346.

Yoo, S.-H. (2007). Student expectations and perceptions of the transition from elementary to middle school. The Journal of Elementary Education, 20(1), 355-375.

\section{ORCID}

Hana Joo http://orcid.org/0000-0002-7851-1949

Ju Hee Park http://orcid.org/0000-0003-3031-0272

Received June 30, 2021

Revision received July 25, 2021

Accepted August 5, 2021 